\title{
Pegfilgrastim Anti-neutropenic Factor
}

National Cancer Institute

\section{Source}

National Cancer Institute. Pegfilgrastim Anti-neutropenic Factor. NCI Thesaurus. Code C123927.

A long-acting, eng ineered and pegylated version of human granulocyte-colony stimulating factor (G-CSF), with potential hematopoietic activity. Similar to G-CSF, peg filgrastim anti-neutropenic factor (ANF) binds to and activates specific cell surface receptors, and stimulates neutrophil progenitor proliferation and differentiation. Therefore, this agent may prevent the duration and incidence of chemotherapy-induced neutropenia. Compared to filgrastim, the conjug ation with a branched polyethylene glycol molecule reduces renal clearance and increases its plasma half-life. 